\title{
Is Diphtheria Booster Vaccination Still Necessary in Turkey?
}

\section{Türkiye'de Difteri Bağışıkı̆̆ı için Rapel Doz Hâlâ Gerekli mi?}

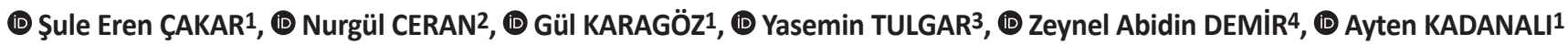 \\ 1 University of Health Sciences, Ümraniye Training and Research Hospital, Clinic of Infectious Diseases and Clinical Microbiology, Istanbul, Turkey \\ 1 University of Health Sciences, Haydarpaşa Training and Research Hospital, Clinic of Infectious Diseases and Clinical Microbiology, Istanbul, \\ Turkey \\ 2Tuzla State Hospital, Clinic of Infectious Diseases and Clinical Microbiology, İstanbul, Turkey \\ 3 Mardin State Hospital, Clinic of Infectious Diseases and Clinical Microbiology, Mardin, Turkey
}

\section{Abstract}

Introduction: Diphtheria is a serious disease that can be prevented by vaccination. The aim of the study was to determine immunity against diphtheria and the necessity of booster doses in the adult population.

Materials and Methods: Serum antibody levels and immunity against diphtheria were determined in 568 healthy participants and results were assessed using chi-square test. Diphtheria antibody level was measured by micro-ELISA technique using NovaTec Corynebacterium diphtheriae toxin IgG ELISA kits (Dietzenbach, Germany). Antitoxin level $<0.1 \mathrm{IU} / \mathrm{mL}$ was considered to be insufficient immunity and level $\geq 0.1 \mathrm{IU} / \mathrm{mL}$ was accepted as full immunity against diphtheria.

Results: A total of 568 individuals were included in the study, [267 (47\%) female and 301 (53\%) male]. Of these, 267 cases (47\%) had full immunity. Immunity distribution rates in each decade beginning from 15 years old were $80.8 \%, 48.4 \%, 24.1 \%, 43.7 \%$, 39.2\%, 50\%, and 53.3\%, respectively. It was observed that females aged 26-35 years had a significantly higher immunity rate than males in the same age group ( $p=0.035$ ).

Conclusion: Adult immunity against diphtheria may only be maintained with routine booster doses of diphtheria toxoid. Tetanus-diphtheria vaccination should be included in the adult immunization program and should be repeated every 10 years.

Keywords: Corynebacterium diphtheriae, epidemiology, community health, vaccinology, public health

\section{Öz}

Giriş: Difteri, aşılama ile korunulabilen ciddi bir hastalıktır. Bu çalışmanın amacı yetişkin popülasyonda difteriye karşı mevcut olan bağışıklık durumunu tespit ederek, rapel doz aşılamanın halen gerekli olup olmadığının ortaya konulmasıdır.

Gereç ve Yöntem: Sağlıklı 568 bireyden alınan kan örneklerinde difteriye karşı oluşmuş olan antikor seviyeleri tespit edildi ve sonuçlar ki-kare testi kullanılarak değerlendirildi. Difteri antikor düzeyi ölçmek için mikro-ELISA yöntemi ve NovaTec Corynebacterium diphtheriae toksin IgG ELISA kiti (Dietzenbach, Almanya) kullanıldı. Antitoksin düzeyi $<0,1 \mathrm{IU} / \mathrm{mL}$ bulunanlar yetersiz bağışı $\mathrm{k}, \geq 0,1 \mathrm{IU} / \mathrm{mL}$ olanlar ise difteriye bağışık olarak kabul edildi.

Bulgular: Çalışmamıza 267'si (\%47) kadın, 301'i (\%53) erkek, toplam 568 kişi dahil edildi. Bireylerin 267'sinde (\%47) tam bağışıklık tespit edildi. On beş yaşından başlayarak her dekat için bağışıklık oranlarının dağılımı sırasıyla \%80,4, \%48,4, \%24, 1, \%43,7, \%39,2, \%50 ve \%53,3 olarak tespit edildi. 26-35 yaş grubu kadınlardaki bağışıklık oranı aynı yaş grubundaki erkeklere göre anlamlı derecede yüksek bulundu ( $p=0,035)$.

Sonuç: Çalışmanın sonunda, yetişkinlerde difteri bağışıklığının devamı için her 10 yılda bir rapel doz aşılamanın devam ettirilmesi gerektiği sonucuna ulaşıldı.

Anahtar Kelimeler: Corynebacterium diphtheriae, epidemiyoloji, toplum sağlığı, aşı bilimi, halk sağlığı

Cite this article as: Çakar ŞE, Ceran N, Karagöz G, Tulgar Y, Demir ZA, Kadanalı A. Is Diphtheria Booster Vaccination Still Necessary in Turkey? Mediterr J Infect Microb Antimicrob. 2018;7:27.

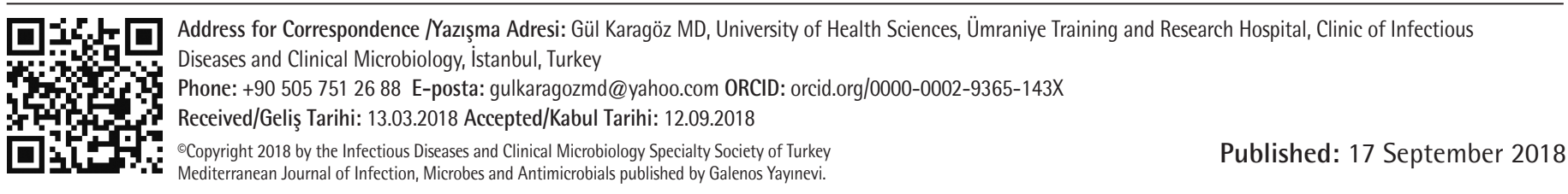




\section{Introduction}

Diphtheria is a life-threatening disease caused by Corynebacterium diphtheriae. It may present as upper respiratory system infection involving the tonsils, larynx, pharynx, and/ or the nasal mucous membranes. Laryngotracheal membrane involvement can be fatal due to respiratory system obstruction. Myocardial, and myocardial and nervous system involvement may also be fatal ${ }^{[1]}$.

The tetanus-diphtheria (Td)-acellular pertussis (Tdap) vaccine was first produced in 1937 and introduced to the routine vaccination program in Turkey in $1968^{[2]}$. Diphtheria is now rare in Turkey, occurring in unvaccinated individuals ${ }^{[3]}$.

However, in recent decades there have been two epidemics affecting all age groups, primarily in Russia and Ukraine, between 1982-1985 and between 1990-1995. These epidemics took place in our neighboring countries but also affected Turkey, with significant increases in the number of cases during those periods. Therefore, immunization is recommended for adults over 25 years of age who are in high-risk groups with a vaccine containing diphtheria toxoid (preferably Td). In recent years, it has been proposed to have at least one dose including acellular pertussis (Tdap) for the adult age group ${ }^{[2]}$.

Although there may be rare complications such as complex regional pain syndrome and transverse myelitis after vaccination, diphtheria is associated with high mortality rates despite all treatment modalities. Therefore, the vaccination program for diphtheria is indispensable for public health ${ }^{[4,5]}$.

In Turkey, Tdap vaccination is applied routinely in 6 doses at 2,4 , and 6 months of age, followed by booster doses given in childhood at 18 months and 7 years, and as a Td toxoid booster in adolescents at 12-14 years of age. Moreover, since 2006, Td vaccination is included in the pregnancy immunity program and in other cases of compulsory tetanus vaccination (e.g., after skin injuries). There is one case of diphtheria reported from Turkey in $2012^{[6]}$.

However, in recent years some clinical presentations consistent with diphtheria and related complications have been observed in adults. This suggests a need for new studies determining seroprevalence ${ }^{[6]}$. This study was designed to survey the rates of diphtheria immunity among adults in the community, evaluate factors related to diphtheria, determine the necessity of booster doses in adults, and thereby contribute to future studies regarding the adult vaccination program. We believe that this study will provide a more accurate representation of diphtheria seroprevalence in Turkey because it was conducted in Istanbul, which is a large metropolitan area that receives migrants from every region of the country.

\section{Materials and Methods}

This study was conducted in 568 individuals in the University of Health Sciences, Haydarpaşa Training and Research Hospital. Ethical approval for the study was obtained from the İstanbul University Faculty of Medicine Ethics Committee (ethics committee approval no: thesis file number 2010/1056-356, number: 373$)$.

Participants aged 15-85 years with no acute illness were chosen randomly from outpatient hospital records (one selected from every three patients who presented to the Infectious Diseases Outpatient Clinics of the hospital). Patients with acute respiratory, urinary, and dermatologic diseases were excluded. Participants were informed about the study by phone. Written consent forms were obtained from the families of patients under 18 years old and from the individuals themselves if over 18 years old. Consenting participants were invited to the hospital for data and blood collection.

Using a previously prepared questionnaire, face-to-face interviews were conducted to collect information about the participants' age, sex, occupation, education level, economic status, place of residence (village, town, city), residence type, vaccination status, regularly used medicines, history of alcohol usage, current chronic illness, military service status for males, history of $\mathrm{Td}$ vaccination during military service, pregnancy status for females, and Td vaccination during the pregnancy period.

Five $\mathrm{ml}$ of venous blood were collected from all participants. Serum samples were separated by centrifuging for 10 minutes at 2000xg and stored at $-80^{\circ} \mathrm{C}$ until testing. Diphtheria antibody level was measured by micro-ELISA technique using NovaTec $C$. diphtheriae toxin IgG ELISA kits (Dietzenbach, Germany).

Antitoxin levels of $<0.1 \mathrm{IU} / \mathrm{mL}$ were accepted as insufficient immunity, while individuals with antitoxin levels $\geq 0.1 \mathrm{IU} / \mathrm{mL}$ were considered fully immune to diphtheria.

\section{Statistical Analysis}

Statistical analysis was performed with Number Cruncher Statistical System 2007 Statistical Software (Utah, USA). In addition to descriptive statistical methods (mediation, standard deviation), chi-square test was used in comparisons of qualitative data. A p value of $<0.05$ was accepted as statistically significant.

\section{Results}

A total of 568 individuals, 267 (47\%) females and 301 (53\%) males, aged 15 to 85 years (mean age $46.3 \pm 18.6$ years) were included in this study. Complete immunity $(\mathrm{lgG} \geq 0.1 \mathrm{IU} / \mathrm{mL})$ for $C$. diphtheriae antitoxin was determined in 267 cases (47\%). There 
was no statistically significant difference between males and females in each age group. Comparison of complete immunity rates according to age group (Table 1) showed significantly higher immunity rate in the 15-25 year age group (80.8\%) compared to the other age groups $(p=0.0001)$. However, there was no statistically significant difference in complete immunity rate among the other age groups (26-35 year, 36-45 year, 46-55 year, 56-65 year, 66-75 year, and over 75 year of age) ( $p>0.05)$. The lowest diphtheria antibody levels (24.1\%) were observed in the 36-45 age group, with a statistically significant difference compared to the other age groups $(p=0.0001)$. When complete immunity was evaluated by gender in each age group, it was observed that females had significantly higher complete immunity rate than males in the 26-35 year age group (60.8\% vs. $40 \%)(p=0.035)$, but no significant gender differences were observed in the other age groups ( $p>0.05$ ) (Table 2).

There were no statistically significant differences in diphtheria antibody levels according to education level, occupation, monthly income, place and type of residence, chronic illness, alcohol usage, or history of adult Td vaccination ( $p>0.05$ ).

Among the participants who did not know their vaccination status, there were no statistically significant differences in full or partial immunity; however, among participants who reported not being vaccinated in childhood, the full immunity rate was significantly lower than partial immunity rate (31.1\% vs. $68.9 \%)$ $(p=0.038)$.

When the military service status was considered, males who had completed their military service had a significantly higher rate of partial immunity compared to full immunity (57.8\% vs. $42.2 \%)(p=0.008)$. However, a statistically significant difference in diphtheria immunity was not observed based on the answers given to the question whether Td vaccination was administered during military service ( $p>0.05$ ). Of those who had completed their military service, 69 men (26.1\%) reported receiving a $\mathrm{Td}$ vaccine, 142 cases (53.8\%) reported not receiving Td vaccine, and 53 cases did not remember whether they received $\mathrm{Td}$ vaccine during their military service.

When pregnancy history status was considered in females, those with previous pregnancy had significantly higher rate of partial immunity compared to full immunity (57.4\% vs. $42.6 \%)$ $(p=0.003)$. A statistical difference in diphtheria immunity was not observed based on the participants' report whether they had been vaccinated during pregnancy and if so, how many doses they had received $(p>0.05)$. Of the 197 women with a history of pregnancy, only 41 (20.8\%) reported having Td vaccination, $147(53.8 \%)$ reported not having it, and $9(4.6 \%)$ did not recall whether they had $\mathrm{Td}$ vaccination during pregnancy. Data collected using the questionnaire are shown in Table 3.
Table 1 . The distribution of antibody levels according to age

\begin{tabular}{|c|c|c|c|c|c|}
\hline \multirow[t]{2}{*}{ Age (years) } & \multicolumn{2}{|c|}{$\begin{array}{l}\text { Incomplete } \\
\text { immunity (IgG } \\
<0.1 \mathrm{IU} / \mathrm{mL} \text { ) }\end{array}$} & \multicolumn{2}{|c|}{$\begin{array}{c}\text { Complete } \\
\text { immunity (IgG } \\
\geq 0.1 \mathrm{IU} / \mathrm{mL})\end{array}$} & \multirow[t]{2}{*}{$\mathbf{p}$} \\
\hline & $n$ & $\%$ & $\mathbf{n}$ & $\%$ & \\
\hline$(15-25)$ & 15 & $19.2 \%$ & 63 & $80.8 \%$ & 0.000 \\
\hline$(26-35)$ & 65 & $51.6 \%$ & 61 & $48.4 \%$ & 0.797 \\
\hline$(36-45)$ & 82 & $75.9 \%$ & 26 & $24.1 \%$ & 0.0001 \\
\hline$(46-55)$ & 40 & $56.3 \%$ & 31 & $43.7 \%$ & 0.634 \\
\hline$(56-65)$ & 45 & $60.8 \%$ & 29 & $39.2 \%$ & 0.187 \\
\hline$(66-75)$ & 33 & $50.0 \%$ & 33 & $50.0 \%$ & 0.699 \\
\hline$(>75)$ & 21 & $46.7 \%$ & 24 & $53.3 \%$ & 0.465 \\
\hline
\end{tabular}

Table 2. The distribution of antibody levels according to age and sex

\begin{tabular}{|c|c|c|c|c|c|c|}
\hline Age (years) & Sex & \multicolumn{2}{|c|}{$\begin{array}{c}\text { Incomplete } \\
\text { immunity (IgG } \\
<0.1 \mathrm{IU} / \mathrm{mL})\end{array}$} & \multicolumn{2}{|c|}{$\begin{array}{c}\text { Complete } \\
\text { immunity (IgG } \\
\geq 0.1 \mathrm{IU} / \mathrm{mL} \text { ) }\end{array}$} & p \\
\hline \multirow{2}{*}{$15-25$} & M & 8 & $20.5 \%$ & 31 & $79.5 \%$ & \multirow{2}{*}{0.774} \\
\hline & $\mathrm{F}$ & 7 & $17.9 \%$ & 32 & $82.1 \%$ & \\
\hline \multirow{2}{*}{$26-35$} & $M$ & 45 & $60.0 \%$ & 30 & $40.0 \%$ & \multirow{2}{*}{0.035} \\
\hline & $\mathrm{F}$ & 20 & $39.2 \%$ & 31 & $60.8 \%$ & \\
\hline \multirow{2}{*}{$36-45$} & $M$ & 45 & $75.0 \%$ & 15 & $25.0 \%$ & \multirow{2}{*}{0.980} \\
\hline & $\mathrm{F}$ & 37 & $77.1 \%$ & 11 & $22.9 \%$ & \\
\hline \multirow{2}{*}{$46-55$} & $M$ & 22 & $56.4 \%$ & 17 & $43.6 \%$ & \multirow{2}{*}{0.989} \\
\hline & $\mathrm{F}$ & 18 & $56.2 \%$ & 14 & $43.8 \%$ & \\
\hline \multirow{2}{*}{$56-65$} & $M$ & 28 & $60.9 \%$ & 18 & $39.1 \%$ & \multirow{2}{*}{0.989} \\
\hline & $\mathrm{F}$ & 17 & $60.7 \%$ & 11 & $39.3 \%$ & \\
\hline \multirow{2}{*}{$66-75$} & $M$ & 11 & $39.3 \%$ & 17 & $60.7 \%$ & \multirow{2}{*}{0.213} \\
\hline & $\mathrm{F}$ & 22 & $57.9 \%$ & 16 & $42.1 \%$ & \\
\hline \multirow{2}{*}{$>75$} & $M$ & 5 & $35.7 \%$ & 9 & $64.3 \%$ & \multirow{2}{*}{0.505} \\
\hline & $\mathrm{F}$ & 16 & $51.6 \%$ & 15 & $48.4 \%$ & \\
\hline \multirow{2}{*}{ Total } & $\mathrm{M}$ & 164 & $54.5 \%$ & 137 & $45.5 \%$ & \multirow{2}{*}{0.501} \\
\hline & $\mathrm{F}$ & 137 & $51.3 \%$ & 130 & $48.7 \%$ & \\
\hline
\end{tabular}

M: Male, F: Female

\section{Discussion}

Diphtheria is a serious infectious disease that can cause respiratory system obstruction and even lead to death. It is caused by exotoxin produced by $C$. diphtheriae. Safe and effective vaccines have saved lives and will continue to do so as long as immunization programs are sustained. However, the disease is still endemic in developing countries (e.g., India, Nigeria, Indonesia, the Philippines, Brazil, and east Mediterranean countries). In developing countries, both children and adults are still at high risk due to inadequate childhood vaccination programs. Although childhood vaccination programs are sufficient in developed countries, booster doses are not administered uniformly. This leads to low immunity rates and 
Table 3. Data collected from the questionnaires

\begin{tabular}{|c|c|c|c|c|c|c|c|c|}
\hline $\begin{array}{l}\text { Occupation } \\
\mathrm{n}(\%)\end{array}$ & $\begin{array}{l}\text { Unemployed } \\
19 \text { (3.3) }\end{array}$ & $\begin{array}{l}\text { Housewife } \\
138(24.3)\end{array}$ & $\begin{array}{l}\text { Worker } \\
54(9.5)\end{array}$ & $\begin{array}{l}\text { Government } \\
\text { official } \\
53(9.3)\end{array}$ & $\begin{array}{l}\text { Retired } \\
86(15.1)\end{array}$ & $\begin{array}{l}\text { Doctor-nurse } \\
41(7.2)\end{array}$ & $\begin{array}{l}\text { Self employed } \\
88(15.3)\end{array}$ & $\begin{array}{l}\text { Others } \\
89(15.7)\end{array}$ \\
\hline $\begin{array}{l}\text { Education } \\
\mathrm{n}(\%)\end{array}$ & $\begin{array}{l}\text { Illiterate } \\
68(12)\end{array}$ & $\begin{array}{l}\text { Literate } \\
26(4.6)\end{array}$ & $\begin{array}{l}\text { Elementary } \\
152(26.8)\end{array}$ & $\begin{array}{l}\text { Middle school } \\
79(13.9)\end{array}$ & $\begin{array}{l}\text { High-school } \\
130-22.9 \%\end{array}$ & $\begin{array}{l}\text { University } \\
113(19.9)\end{array}$ & & \\
\hline $\begin{array}{l}\text { Income (month) } \\
\mathrm{n}(\%)\end{array}$ & $\begin{array}{l}<500 \\
130(22.9)\end{array}$ & $\begin{array}{l}500-1000 \\
258(45.4)\end{array}$ & $\begin{array}{l}1000-2000 \\
131(23.1)\end{array}$ & $\begin{array}{l}>2000 \\
49(8.6)\end{array}$ & & & & \\
\hline $\begin{array}{l}\text { Resident in } \\
\mathrm{n}(\%)\end{array}$ & $\begin{array}{l}\text { Village } \\
30(5.3)\end{array}$ & $\begin{array}{l}\text { Town } \\
21(3.7)\end{array}$ & $\begin{array}{l}\text { City } \\
517 \text { (91) }\end{array}$ & & & & & \\
\hline $\begin{array}{l}\text { Vaccination in } \\
\text { childhood } \\
n(\%)\end{array}$ & $\begin{array}{l}\text { Yes } \\
290(51.1)\end{array}$ & $\begin{array}{l}\text { No } \\
45 \text { (7.9) }\end{array}$ & $\begin{array}{l}\text { Unknown } \\
233(41)\end{array}$ & & & & & \\
\hline $\begin{array}{l}\text { Chronic medication } \\
\mathrm{n}(\%)\end{array}$ & $\begin{array}{l}\text { Yes } \\
167(24.4)\end{array}$ & $\begin{array}{l}\text { No } \\
517(75.6)\end{array}$ & & & & & & \\
\hline $\begin{array}{l}\text { Alcohol consumption } \\
\mathrm{n}(\%)\end{array}$ & $\begin{array}{l}\text { Yes } \\
105(18.5)\end{array}$ & $\begin{array}{l}\text { No } \\
462(81.5)\end{array}$ & & & & & & \\
\hline $\begin{array}{l}\text { Chronic disease } \\
\text { n }(\%)\end{array}$ & $\begin{array}{l}\text { Yes } \\
231(37.5)\end{array}$ & $\begin{array}{l}\text { No } \\
355(62.5)\end{array}$ & & & & & & \\
\hline $\begin{array}{l}\text { Military history } \\
\mathrm{n}(\%)\end{array}$ & \begin{tabular}{|l} 
Yes \\
$263(87.7)$
\end{tabular} & $\begin{array}{l}\text { No } \\
38(12.3)\end{array}$ & & & & & & \\
\hline $\begin{array}{l}\text { Td vaccine during } \\
\text { military service } \\
\text { n (\%) }\end{array}$ & $\begin{array}{l}\text { Yes } \\
69(26.1)\end{array}$ & $\begin{array}{l}\text { No } \\
142(53.8)\end{array}$ & $\begin{array}{l}\text { Unknown } \\
53(20.1)\end{array}$ & & & & & \\
\hline $\begin{array}{l}\text { Pregnancy } \\
\mathrm{n}(\%)\end{array}$ & $\begin{array}{l}\text { Yes } \\
197 \text { (73.8) }\end{array}$ & $\begin{array}{l}\text { No } \\
70(26.2)\end{array}$ & & & & & & \\
\hline $\begin{array}{l}\text { Td vaccine during } \\
\text { pregnancy } \\
\text { n (\%) }\end{array}$ & $\begin{array}{l}\text { Yes } \\
41(20.8)\end{array}$ & $\begin{array}{l}\text { No } \\
147(74.6)\end{array}$ & $\begin{array}{l}\text { Unknown } \\
9(4.6)\end{array}$ & & & & & \\
\hline
\end{tabular}

Td: Tetanus-diphtheria

puts adults at risk for diptheria ${ }^{[1,7,8]}$. In 2018, Hübschen et al. ${ }^{[9]}$ reported that $C$. diphteria $\lg G$ antibody prevalence suggested high immunization needs in newcomers to Luxembourg in 2012, with only $73 \%$ of the study group having safe protection against diphtheria. These newcomers were from developing countries in the Balkans, Middle East, Asia, and Africa. In another 2018 publication, Freidl et al. ${ }^{[10]}$ reported a low diphtheria immunity rate among asylum-seekers in the Netherlands in 2016. Full protection rates were 62\% for Iran, 27\% for Afghanistan, and $28 \%$ for Iraq, which were the lowest rates in the Netherlands.

In 2000, a multinational study by the European SeroEpidemiology Network Project was conducted in Finland, France, the Netherlands, Sweden, Italy, Germany, and the United Kingdom. The authors reported that complete immunity rate was $70 \%$ in adult age group in this study. Moreover, gender distribution analysis showed that diphtheria immunity rates were significantly higher among males in the Netherlands, Finland, Sweden, and France ${ }^{[11]}$.

In our study, high immunity rates in the 15-25 year age group were a result of the effective primary vaccination. As primary diphtheria immunization has been implemented since 1968, low antibody levels in the 36-45 age group (those born between 1965 and 1975) are likely due to the years before routine primary vaccination. In the 56-65 age group, diphtheria antibody levels were $39 \%$ and then raised to $53 \%$ in the over 75 age group, which is probably a result of natural immunity to diphtheria.

Zasada et al. ${ }^{[12]}$ reported in 2013 that of 1387 individuals in Poland, diphtheria antibody titers were below $0.1 \mathrm{IU} /$ $\mathrm{mL}$ in $36.9 \%$ of those aged $\leq 18$ and in $40.5 \%$ of those $>18$, with inadequate immunity at a rate of $39.4 \%$ across all age groups. Dragomirescu et al. ${ }^{[13]}$ conducted a study in Romania with 438 individuals aged 20-39 years and determined rates of diphtheria protection of $56.6 \%$ in the $20-29$ age group and $31.7 \%$ in the 30-39 age group. In 2018, Barreto et al. ${ }^{[14]}$ studied humoral immunity 5 years after booster immunization in adults who received Td vaccine at 18 to 60 years of age. Diphtheria antibody titer $>0.1 \mathrm{IU} / \mathrm{mL}$ was accepted as full protection and was detected in $56.8 \%$ of the study population 5 years after the last Td booster dose. Esteve et al. ${ }^{[15]}$ conducted a study in Catalonia in 2012 with 537 healthcare workers. Protective antibody levels against diphtheria were estimated as 46.4\% in their study. Seroprevalence evaluation based on age groups indicated significantly lower diphtheria protection in those born before 1975. Hence, in most of the recent studies, it can be observed that diphtheria antibody seronegativity in adults is around 50\% in Europe. 
When we look at Asian studies, Ang et al. ${ }^{[16]}$ published a study including 3293 cases in 2015. They reported 92\% protective diphtheria antibody levels in adults 18-79 years of age but a significantly lower level was observed in the 50-59 age group. In another sero-epidemiological study held in Tajikistan in 2010, the diphtheria seropositivity rate was calculated as $51.4 \%$ in the 1-24 year age group ${ }^{[17]}$. Wanlapacorn et al. ${ }^{[18]}$ carried out a study with 890 cases from seven different regions of Thailand. They concluded that protective antibody rates range from $83 \%$ to $99 \%$ and diphtheria antibody levels decreased as age increased. Moreover, they recommended one dose of $\mathrm{Td}$ vaccine after age 20 with boosters every 10 years. In 2018, Halperin et al. ${ }^{[19]}$ reported that revaccination with either Tdap or Td vaccine in adults between 18-65 years resulted in similar rates of full immunity (diphtheria antibody $>0.1 \mathrm{IU} / \mathrm{mL}$ ) after 10 years (87.7\% vs. $88.0 \%)$.

In Turkey, Alp Cavus et al. ${ }^{[3]}$ carried out a study in İzmir with 339 patients in 2007 and determined 46.3\% full diphtheria immunity. When diphtheria immunity was analyzed in terms of age, the lowest level (30\%) was found in the 40-49 age group. There was no statistical difference in diphtheria immunity based on gender. In Edirne, Tansel et al. ${ }^{[20]}$ identified full immunity at a rate of 98\% in the 15-80 year age group in their 2009 study. In 2011, Kurugöl et al. ${ }^{[21]}$ performed another study in İzmir with 599 individuals ranging in age from 1 to 70 years and reported full diphtheria immunity in $72.3 \%$. When age distribution was taken into consideration, they found the highest rate (86\%) in the 15-19 age group and the lowest rate (47.3\%) in 30-39 age group. Gender analysis revealed statistically lower diphtheria antibody levels in females compared to males (67.1\% vs. 80.9\%). When they analyzed immunity according to both gender and age, full immunity was more common in males than females in the $20-29$ age group ( $80 \%$ vs. $46.2 \%$ ) and in the $30-39$ age group (60\% vs. $44.1 \%)$. In contrast, in the present study we observed significantly lower seropositivity rates in males than in females in the $26-35$ age group ( $40 \%$ vs. $>60 \%$ ).

Astudy by Völzke et al. ${ }^{[22]}$ included 4275 cases in Germany between 1997 and 2001. They compared diphtheria seroprevalence with demographic characteristics. Diphteria susceptibility rate $(<0.1$ $\mathrm{IU} / \mathrm{mL}$ ) was found to be $32.4 \%$, which was lower than the rate of full immunity in our study (47\%). They identified older age, female gender, low education level, not being single, and being unvaccinated for diphtheria and tetanus as factors associated with greater susceptibility to diphtheria. Diphtheria sensitivity was determined to be 4 times higher in females than males that had not been vaccinated within the last 10 years.

In our study, we evaluated 568 individuals aged 15 years or older. We determined that only $47 \%$ of the individuals in our study had adequate protection against diphtheria. There were no statistically significant differences in immunity rates between the male and female groups. With the exception of two studies, no statistically significant gender differences in diphtheria seropositivity have been reported ${ }^{[21,23]}$. All studies have suggested that diphtheria immunity decreases with age and booster doses for diphtheria are needed to maintain high immunity.

In our study, the highest immunity rates were observed in the $15-25$ year age group (>80\%). Although there were similar rates in other groups, seropositivity was determined as $24 \%$ in the $36-45$ years age group. Seropositivity in males was statistically lower than females ( $40 \%$ vs. $60 \%>$ ) in the $26-35$ age group. This difference could be a result of the implementation of Td vaccination during pregnancy in Turkey over the last decade. Demographic characteristics such as economic status, education as well as place and type of residence were not associated with level of immunity. Moreover, in our study, the higher immunity rates in males who had completed their military service and in females who had at least one pregnancy may be attributed to booster dose vaccination with $\mathrm{Td}$ during military service experience or during pregnancy period.

When we compare our results with earlier reports, sufficient diphtheria immunity levels are significantly lower than those reported previously. The probable reason for this difference is that Istanbul is the largest cosmopolitan city in Turkey with immigrants from all over the country where vaccination rates are low. Furthermore, there are increasing recent opposing opinions about certain vaccination programs in Turkey (like rubella and mumps vaccines, etc.) that probably influence and lower compliance with other vaccination programs like diphtheria vaccines.

\section{Conclusion}

In conclusion, this study demonstrates that insufficient diphtheria immunity rates are still high in İstanbul and this rate was not influenced by gender, education level, or economic status. Moreover, lower antibody levels with older age are evidence of inadequate vaccination rates. According to a study conducted in Canada by Halperin et al. ${ }^{[24]}$, recommendations by family physicians were the most influential factor in public decisions. Based on this study, Turkish family physicians also have great power to increase diphtheria immunity rates by educating people about the effectiveness and safety of vaccines and the implementation of $\mathrm{Td}$ vaccine every ten years. In addition, screening for diphtheria booster immunization can be done in community settings like universities, the military, and hospital outpatient clinics, and booster doses may be given if not applied within the last 10 years.

\section{Acknowledgements}

We are thankful to our colleagues Şenol Çomoğlu, Mehmet Fatih Bektaşoğlu and Paşa Göktaş for their contribution to the study. 
We are also grateful to Seyfi Çelik Özyürek who evaluated this study and in that line improved the manuscript significantly.

\section{Ethics}

Ethics Committee Approval: The study was approved by the İstanbul University Faculty of Medicine Ethical Committee (ethics committee approval no: thesis file number 2010/1056356, number: 373 ).

Informed Consent: Consent form was filled out by all participants.

Peer-review: Externally and internally peer-reviewed.

\section{Authorship Contributions}

Surgical and Medical Practices: Ş.E.Ç., Y.T., Concept: N.C., Design: N.C., Data Collection or Processing: Ş.E.Ç., Z.A.D., Y.T., Analysis or Interpretation: N.C., A.K., Literature Search: Ş.E.Ç., G.K., Z.A.D., Writing: G.K.

Conflict of Interest: No conflict of interest was declared by the authors.

Financial Disclosure: The authors declared that this study received no financial support.

\section{References}

1. MacGregor RR. Corynebacterium diphtheriae. In: Mandell G L, Bennett JE, Dolin R, (eds). Mandell, Douglas, and Bennett's Principles and Practices of Infectious Diseases. Philedelphia: Churchill Livingstone Elsevier. 2015:236673.

2. Türkiye EKMUD Erişkin Bağışıklama Rehberi $2^{\text {nd }}$ update 2016. Available from: http://meramtip.com.tr/kalite/dosyalar/rehberler/eriskin-bagisiklama/ EriskinBagisiklamaRehberi.pdf. Last accessed date: 13.03.2018

3. Alp Cavus S, Avkan Oguz V, Yuce A. The seroprevalence of diphtheria among adults in Izmir-Turkey. Vaccine. 2007;25:3851-4.

4. Bilic E, Bilic E, Zagar M, Cerimagic D, Vranjes D. Complex regional pain syndrome type I after diphtheria-tetanus (Di-Te) vaccination. Coll Antropol. 2013;37:1015-8.

5. Riel-Romero RM. Acute transverse myelitis in a 7-month-old boy after diphtheria-tetanus-pertussis immunization. Spinal Cord. 2006;44:688-91.

6. Ornek E, Ureyen CM, Kurtul A, Oksüz F. Diphtheria myocarditis in Turkey after years. Anatol J Kardiyol Derg. 2012;12:279-80.

7. Kliegman RM, Stanton B, Geme JS, Schor NF, Behrman RE. $19^{\text {th }}$ ed. Nelson Textbook of Pediatrics. Philadelphia, PA: Elsevier/Saunders. 2011:881-9.

8. Karatas $\mathrm{E}_{1}$ Aydemir S. Corynebacterium diphtheriaeve diger Corynebacterium türleri. In: Topcu AW SG, Söyletir G, Doganay M, eds. Enfeksiyon Hastalıkları ve Mikrobiyolojisi. $4^{\text {th }}$ ed. Istanbul: Nobel Tıp Kitapevleri, 2017:1816-21.

9. Hübschen JM, Charpentier E, Weicherding P, Muller CP. IgG antibody prevalence suggests high immunization needs in newcomers to Luxembourg 2012. Vaccine. 2018;36:899-905.

10. Freidl GS, Tostmann A, Curvers M, Ruijs WLM, Smits G, Schepp R, Duizer $E$, Boland $G$, de Melker $H$, van der Klis FRM, Hautvast JLA, Veldhuijzen IK.
Immunity against measles, mumps, rubella, varicella, diphtheria, tetanus, polio, hepatitis $A$ and hepatitis B among adult asylum seekers in the Netherlands, 2016. Vaccine. 2018;36:1664-72.

11. Edmunds WJ, Pebody RG, Aggerback $H$, Baron $S$, Berbers G, Conyn-van Spaendonck MA, Hallander HO, Olander R, Maple PA, Melker HE, Olin P, Fievret-Groyne F, Rota C, Salmaso S, Tischer A, von-Hunolstein C, Miller E. The sero-epidemiology of diphtheria in Western Europe. ESEN Project. European Sero-Epidemiology Network. Epidemiol Infect. 2000;125:113-25.

12. Zasada AA, Rastawicki W, Rokosz N, Jagielski M. Seroprevalence of diphtheria toxoid IgG antibodies in children, adolescents and adults in Poland. BMC Infect Dis. 2013;13:551.

13. Dragomirescu CC, Coldea IL, Ilie A, Stanescu A, Ungureanu V, Popa MI. Seroprevalence study of anti diphtheria antibodies in two age-groups of Romanian adults. Roum Arch Microbiol Immunol. 2014;73:18-24.

14. Barreto L, Guasparini R, Meekison W, Noya F, Young L, Mills E. Humoral immunity 5 years after booster immunization with an adolescent and adult formulation combined tetanus, diphtheria, and 5-component acellular pertussis vaccine. Vaccine. 2007;25:8172-9.

15. Esteve $M$, Dominguez A, Urbiztondo L, Borrás $E$, Costa J, Broner $S$, Campins M, Bayas JM; Working Group for the Study of the Immune Status in Healthcare Workers in Catalonia. Prevalence of susceptibility to tetanus and diphtheria in health care workers in Catalonia. Am J Infect Control. 2012;40:896-8.

16. Ang LW, James L, Goh KT. Prevalence of diphtheria and tetanus antibodies among adults in Singapore: a national serological study to identify most susceptible population groups. J Public Health (Oxf). 2016;38:99-105.

17. Khetsuriani N, Zakikhany K, Jabirov S, Saparova N, Ursu P, Wannemuehler K, Wassilak S, Efstratiou A, Martin R. Seroepidemiology of diphtheria and tetanus among children and young adults in Tajikistan: nationwide population-based survey, 2010. Vaccine. 2013;31:4917-22.

18. Wanlapakorn $N$, Yoocharoen $P$, Tharmaphornpilas $P$, Theamboonlers $A$, Poovorawan Y. Diphtheria outbreak in Thailand, 2012; seroprevalence of diphtheria antibodies among Thai adults and its implications for immunization programs. Southeast Asian J Trop Med Public Health. 2014;45:1132-41.

19. Halperin SA, Donovan C, Marshall GS, Pool V, Decker MD, Johnson DR, Greenberg DP; Tdap Booster Investigators. Randomized Controlled Trial of the Safety and Immunogenicity of Revaccination With Tetanus-DiphtheriaAcellular Pertussis Vaccine (Tdap) in Adults 10 Years After a Previous Dose. J Pediatric Infect Dis Soc. 2018. doi: 10.1093/jpids/pix113

20. Tansel O, Ekuklu G, Eker A, Kunduracilar H, Yulugkural Z, Yüksel P. Community-based seroepidemiology of diphtheria and tetanus in Edirne, Turkey. Jpn J Infect Dis. 2009;62:275-8.

21. Kurugöl Z, Midyat L, Türkoğlu E, Isler A. Immunity against diphtheria among children and adults in Izmir, Turkey. Vaccine. 2011;29:4341-4.

22. Völzke $H$, Kloker KM, Kramer $A$, Guertler L, Dören $M$, Baumeister SE, Hoffmann W, John U. Susceptibility to diphtheria in adults: prevalence and relationship to gender and social variables. Clin Microbiol Infect. 2006;12:961-7.

23. Maple PA, Efstratiou A, George RC, Andrews NJ and Sesardic D. Diphtheria immunity in UK blood donors. Lancet. 1995;345:963-5.

24. Halperin BA, MacDougall D, MacKinnon-Cameron D, Li L, McNeil SA Langley JM, Halperin SA. Universal tetanus, diphtheria, acellular pertussis (Tdap) vaccination of adults: What the Canadian public knows and wants to know. Vaccine. 2015;33:6840-8. 